\title{
PROGRAM PENGAMPUNAN PAJAK DI INDONESIA: PELUANG DAN HARAPAN KEBERHASILANNYA
}

\author{
Setiadi Alim Lim \\ Program Studi Akuntansi Politeknik Ubaya \\ Jalan Ngagel Jaya Selatan 169, Surabaya \\ Lilik Indrawati \\ Program Studi Manajemen \\ Fakultas Ekonomi Universitas Katolik Darma Cendika \\ Jalan Dr. Ir. H. Soekarno 201, Surabaya
}

\begin{abstract}
Tax amnesty program is one instrument that is used widely by the tax authorities in many countries in order to increase tax revenue, broaden the tax base, improve tax compliance and other purposes. In addition to having a large role in increasing tax revenue, tax amnesty program also may be adversely affected as opposed to the benefits generated. Not all countries implement tax amnesty program success in implementing it. Experiences in the tax amnesty implementation in several countries showed that the program of tax amnesty are carried out several times and the implementation time was easily anticipated by the taxpayer generally not as successful if the program of tax amnesty is only a one-time, non-recurring and can not be anticipated time of its implementation by the taxpayer. In 2016 the Government of Indonesia to implement tax amnesty program that will be implemented starting on July 1, 2016 to March 31, 2017. After going through the analysis based on the experience of implementation of tax amnesty program conducted by several other countries can be predicted that the tax amnesty program implemented by the Government of Indonesia will be a success. Tax amnesty program implemented is estimated to have a great opportunity to meet the expectations of increasing tax revenue, broaden the tax base, improve tax compliance significantly. However, for the hope of repatriation of assets of the taxpayer from abroad into the country seems not to be able to meet expectations.
\end{abstract}

\begin{abstract}
ABSTRAK
Program pengampunan pajak merupakan salah satu instrumen yang digunakan secara luas oleh otoritas pajak di banyak negara dalam rangka meningkatkan penerimaan pajak, memperluas basis pajak, meningkatkan kepatuhan wajib pajak dan tujuan-tujuan lainnya. Di samping mempunyai peranan yang besar dalam meningkatkan penerimaan pajak, program pengampunan pajak juga dapat memberikan dampak negatif yang berlawanan dengan manfaat yang ditimbulkan. Tidak semua negara yang melaksanakan program pengampunan pajak berhasil
\end{abstract}


sukses dalam mengimplementasikannya. Pengalaman pelaksanaan program pengampunan pajak di beberapa negara menunjukkan bahwa program pengampunan pajak yang dilaksanakan beberapa kali dan waktu pelaksanaannya mudah diantisipasi oleh wajib pajak umumnya tidak sesukses jika program pengampunan pajak tersebut hanya dilakukan satu kali saja, tidak berulang dan tidak dapat diantisipasi waktu pelaksanaannya oleh wajib pajak. Pada tahun 2016 Pemerintah Indonesia melaksanakan program pengampunan pajak yang akan diimplementasikan mulai tanggal 1 Juli 2016 sampai dengan 31 Maret 2017. Setelah melalui analisis berdasarkan pengalaman pelaksanaan program pengampunan pajak yang dilakukan oleh beberapa negara lain dapat diprediksi bahwa program pengampunan pajak yang dilaksanakan oleh Pemerintah Indonesia ini akan sukses. Program pengampunan pajak yang dilaksanakan ini diperkirakan mempunyai peluang besar untuk memenuhi harapan meningkatkan penerimaan pajak, memperluas basis pajak, meningkatkan kepatuhan wajib pajak secara signifikan. Namun untuk harapan repatriasi aset wajib pajak dari luar negeri ke dalam negeri kelihatannya belum akan dapat memenuhi ekspektasi.

Keywords: tax amnesty, multiply tax amnesty, single tax amnesty.

\section{PENDAHULUAN}

Pajak merupakan sumber pendapatan utama dari semua negara di seluruh dunia. Apabila penerimaan dari sektor pajak suatu negara mengalami penurunan, maka negara tersebut akan mengalami kesulitan untuk membiayai pengeluarannya yang terdiri dari pengeluaran rutin seperti untuk pembayaran gaji pegawai pemerintah, dan pengeluaran non rutin seperti pengeluaran untuk pembangunan infrastuktur. Stewart (2011) dalam Nar (2015) menyatakan saat ini pendapatan dari pajak merupakan bagian penting dari pendapatan publik dan pengumpulan pendapatan dari pajak menjadi suatu isu yang penting.

Dalam pengumpulan pendapatan dari sektor pajak setiap negara umumnya berhadapan dengan masalah yang berkaitan dengan tingkat kepatuhan dari wajib pajak. Setiap wajib pajak mempunyai kecenderungan sifat untuk menghindar membayar pajak.
Seperti yang dikatakan oleh Mattiello (2005) bahwa ada 3 hal yang pasti dalam hidup yaitu: kematian, pajak dan kita akan mencoba untuk menghindari keduanya. Banyak wajib pajak yang menghindar untuk membayar pajak, baik melalui tindakan yang melanggar ketentuan Undang-Undang Perpajakan (tax evasion) maupun melalui manuver-manuver dan rekayasa yang tidak bertentangan dengan Undang-Undang Perpajakan (tax avoidance).

Tindakan wajib pajak tersebut baik yang melanggar maupun tidak melanggar Undang-Undang Perpajakan telah menggerogoti pendapatan pajak dari semua negara di seluruh dunia. Farrar et al. (2014) menyatakan bahwa cost dari ketidakpatuhan wajib pajak di seluruh dunia sangat mengejutkan. Sebagai contoh estimasi tax gap akibat dari penghasilan yang dilaporkan lebih rendah dari yang sebenarnya di Amerika Serikat mencapai 
angka sebesar US\$ 450 milyar dan di Kanada sebesar US\$ 80 milyar.

Karena itu kepatuhan dari wajib pajak merupakan salah satu unsur yang terpenting bagi keberhasilan suatu negara dalam melakukan pemungutan pajak. Farrar et al. (2014) menyatakan penelitian kepatuhan wajib pajak cenderung menguji faktor-faktor yang dapat meningkatkan kepatuhan wajib pajak dan mencegah tax evasion. Umumnya setiap negara telah mempunyai aturan yang akan memberikan sanksi kepada wajib pajak yang tidak patuh, baik berupa sanksi administrasi mau-pun sanksi pidana. Farrar et al. (2014) menyatakan secara khusus penggunaan sanksi dan hukuman untuk mencegah tax evasion sementara efektif, tetapi pendekatan ini very costly. Karena itu otoritas pajak cenderung mencari cara-cara yang lain guna meningkatkan kepatuhan wajib pajak. Salah satu cara yang banyak digunakan untuk meningkatkan kepatuhan wajib pajak adalah dengan program pengampunan pajak (tax amnesty). Pengampunan pajak adalah kebijakan dari otoritas pajak yang memberikan kesempatan bagi wajib pajak untuk memperbaiki laporan pajak (Surat Pemberitahuan) yang telah disampaikannya dan membayar pajak yang kurang dibayar tanpa dikenakan sanksi administrasi dan atau sanksi pidana. Kebijakan pengampunan pajak ini dapat pula meliputi pemberian tarif pajak dan dasar pengenaan pajak khusus yang lebih ringan dari tarif dan dasar pengenaan pajak normal.

Ada negara-negara yang mengambil kebijakan pengampunan pajak hanya pada saat tertentu saja. Tetapi ada pula beberapa negara yang menggunakan kebijakan pengampunan pajak berulang-ulang, seperti Argentina,
Perancis, India, Irlandia dan Italia yang menawarkan kebijakan pengampunan pajak beberapa kali dan kadangkadang mengulangi kebijakan pengampunan pajak untuk setiap suatu jangka waktu pendek tertentu, misalnya setiap 2 tahun sekali (Kilonzo, 2012).

Kebijakan pengampunan pajak yang diambil diharapkan akan mampu menarik pihak-pihak yang sebelumnya tidak pernah membayar pajak sama sekali atau yang masih kurang membayar pajak agar mau mengikuti program pengampunan pajak ini dengan melaporkan dan membayar pajak yang belum dilaporkan sebelumnya. Dalam jangka pendek dan jangka panjang kebijakan pengampunan pajak ini akan dapat meningkatkan penerimaan dari sektor pajak.

Krisis keuangan yang melanda dunia pada tahun 2008 dan dampaknya masih terasa sampai sekarang. Pasca krisis keuangan global ini banyak negara yang mengalami pelebaran defisit keuangan pada anggaran pendapatan dan belanjanya. Hal ini seperti yang diungkapkan oleh Nar (2015) bahwa secara khusus setelah krisis ekonomi tahun 2008 banyak negara yang mengalami peningkatan defisit keuangan publiknya dan membutuhkan peningkatan pendapatan dari sektor pajaknya dalam jumlah yang besar serta membutuhkan kerjasama global untuk memerangi tax loss and evasion. Salah satu kebijakan yang merupakan soft enforcement untuk memerangi tax loss and evasion adalah program pengampunan pajak. Hal ini sesuai yang dikatakan oleh Bayer et al. (2015) bahwa banyak pemerintah di seluruh dunia yang menghadapi defisit keuangan publik setelah krisis keuangan baru-baru ini, berinisiatif mengambil 
kebijakan pengampunan pajak untuk memenuhi kebutuhan fiskalnya.

Indonesia seperti kebanyakan negara emerging market lainnya sebenarnya cukup tahan terhadap goncangan badai krisis keuangan tahun 2008 . Namun setelah beberapa tahun pasca krisis keuangan, recovery ekonomi global tidak menunjukkan hasil seperti yang diharapkan, maka perlahan tapi pasti kondisi ekonomi negara-negara emerging market mulai terpengaruh. Kalau sebelumnya tingkat pertumbuhan ekonomi negara-negara emerging market cenderung tinggi, namun pada 2 atau 3 tahun terakhir tingkat pertumbuhan ekonominya cenderung menurun terus. Penurunan tingkat pertumbuhan ekonomi negara-negara yang tergolong emerging market, khususnya negara-negara pengekspor komoditas salah satunya disebabkan karena melambatnya pertumbuhan ekonomi di Tiongkok. Perlambatan pertumbuhan ekonomi di Tiongkok menyebabkan permintaan komoditas global menurun dengan tajam dan pada akhirnya mengakibatkan turunnya harga komoditas. Indonesia sebagai salah satu negara yang ekspornya didominasi produk komoditas sangat merasakan tekanan terhadap turunnya harga dan jumlah permintaan komoditas. Volume dan nilai ekspor Indonesia menurun dengan sangat tajam. Hal ini semua berakibat terhadap pemasukan negara dari sektor pajak dan non pajak mengalami penurunan yang dapat berakibat pada makin sempitnya ruang fiskal dan peningkatan defisit anggaran. Pada tahun berjalan 2016, setelah melihat realisasi penerimaan beberapa bulan yang sudah lewat dan memprediksi peluang penerimaan beberapa bulan berikutnya dalam tahun berjalan, Pemerintah Indonesia meng- estimasi bahwa target penerimaan negara dalam tahun 2016, khususnya dari sektor pajak tidak akan tercapai. Merespon hal tersebut Pemerintah Indonesia mengambil berbagai langkah kebijakan untuk pengendalian pengeluaran serta peningkatan penerimaan, khususnya dari sektor pajak, antara lain dengan cara mengambil kebijakan menjalankan program pengampunan pajak yang akan dilaksanakan mulai tanggal 1 Juli 2016 sampai dengan 31 Maret 2017.

Program pengampunan pajak yang dilaksanakan diharapkan akan mampu meningkatkan kepatuhan wajib pajak dengan melaporkan semua penghasilan yang belum dilaporkan sebelumnya atau sudah dilaporkan tetapi belum semuanya. Karena penghasilan yang belum dilaporkan sebagian atau semuanya diperoleh pada tahun-tahun yang lalu, maka tidak mungkin bagi wajib pajak untuk menelusuri kembali jumlah penghasilan yang belum dilaporkan tersebut. Cara yang digunakan adalah wajib pajak diminta untuk mendeklarasikan jumlah aset bersih yang diperoleh dengan menggunakan penghasilan sejak tahun 1985 sampai tahun 2015. Selisih aset bersih yang dideklarasikan tersebut dengan aset bersih yang telah dilaporkan di dalam Surat Pemberitahuan (SPT) Tahunan Pajak Penghasilan Tahun 2015 akan dikenakan Pajak Penghasilan dengan tarif $2 \%, 3 \%$ dan $5 \%$ untuk deklarasi aset di dalam negeri serta repatriasi aset dari luar negeri ke dalam negeri, dan tarif 4\%, 6\% dan $10 \%$ untuk deklarasi aset di luar negeri. Untuk pengusaha yang tergolong UMKM (Usaha Mikro, Kecil dan Menengah), yaitu wajib pajak yang memiliki peredaran usaha dalam tahun terakhir sampai dengan Rp. 4.800.000.000,- 
diberikan tarif khusus yaitu $0,5 \%$ dan $2 \%$.

Program pengampunan pajak yang dilaksanakan oleh Pemerintah Indonesia mulai tanggal 1 Juli 2016 sampai dengan 31 Maret 2017 memberikan insentif kepada semua wajib pajak yang memenuhi persyaratan untuk mengungkapkan semua aset bersihnya yang diperoleh dari penghasilan yang belum pernah dilaporkan atau dilaporkan kurang dari yang sebenarnya dengan membayar uang tebusan dengan tarif rendah serta dibebaskan dari sanksi administrasi dan sanksi pidana. Pada tulisan ini akan dibahas mengenai program pengampunan pajak yang dilaksanakan oleh Pemerintah Indonesia, mengenai kemungkinan keberhasilan program ini dalam meningkatkan pendapatan dari sektor pajak, baik untuk jangka pendek maupun jangka panjang dan meningkatkan kepatuhan wajib pajak, serta dampak negatif yang mungkin timbul dari pelaksanaan program pengampunan pajak ini, mengingat tidak semua negara berhasil dalam mengimplementasikan program pengampunan pajak.

\section{PENGERTIAN PENGAMPUNAN PAJAK}

Pengampunan pajak adalah istilah yang digunakan untuk menggambarkan penawaran yang bersifat khusus pada suatu saat untuk melunasi jumlah pajak yang kurang dibayar dari utang pajak saat ini. Dengan kata lain pendekatan ini berarti memungkinkan wajib pajak untuk membayar utang pajak yang belum dibayar dalam keadaan yang sesuai tanpa menimbulkan biaya keterlambatan dan denda lainnya (Wisegeek, 2014 dalam Nar, 2015). Mattiello (2005) menyatakan pengam- punan pajak memungkinkan wajib pajak untuk mendeklarasikan penghasilan yang selama ini dihindarkan dari pengenaan pajak untuk diungkapkan tanpa ada hukuman lebih lanjut dengan membayar tarif pajak tambahan yang rendah. Menurut Alm et al. (2007) program pengampunan pajak mengizinkan orang pribadi atau badan usaha untuk membayar pajak yang lalai dibayarnya tanpa mendapatkan hukuman denda keuangan dan pidana.

Andreoni (1991) menyatakan pengampunan pajak adalah program pemerintah yang mengampuni semua atau sebagian dari hukuman yang harus ditanggung oleh pihak yang memanipulasi pajak, jika mereka secara sukarela membayar tunggakan pajak mereka. Hal senada diungkapkan oleh Mouloud (2015) yang menyatakan pengampunan pajak merupakan program pemerintah untuk memungkinkan warga negara secara sukarela membayar pajak yang dihindarinya sebelumnya tanpa ada hukuman tambahan.

Jadi program pengampunan pajak merupakan suatu kebijakan khusus yang diambil oleh pemerintah, baik pemerintah pusat maupun pemerintah daerah dari suatu negara dengan memberikan suatu keringanan, berupa penghapusan sanksi denda, sanksi pidana dan sanksi lainnya serta mungkin ditambah keringanan pengenaan tarif pajak yang lebih rendah dari pada tarif normal kepada wajib pajak yang mau secara sukarela membayar dan melaporkan jumlah pajak yang masih kurang dibayar pada waktu-waktu yang lalu, berhubungan dengan berbagai jenis pajak yang menjadi kewajibannya. Program pengampunan pajak ini dapat meliputi pajak yang dipungut oleh Pemerintah Pusat ataupun Pemerintah Daerah, dan dapat berupa Pajak Peng- 
hasilan, Pajak Pertambahan Nilai dan jenis-jenis pajak lainnya.

Program pengampunan pajak ini dapat dilakukan hanya satu kali saja atau beberapa kali secara teratur atau tidak teratur. Suatu negara dapat mengambil kebijakan melaksanakan program pengampunan pajak satu kali saja dan tidak akan pernah dilakukan lagi. Namun dapat juga suatu negara mengambil kebijakan pengampunan pajak beberapa kali, tetapi tidak sering dan tidak rutin dengan jangka waktu yang tidak tertentu disesuaikan dengan kebutuhan. Tapi ada pula negara yang sering melakukan program pengampunan pajak dan dijadikan program rutin setiap jangka waktu tertentu, misalkan setiap 2 tahun atau 3 tahun sekali.

Kilonzo (2012) menyatakan banyak negara maju seperti halnya negara berkembang melaksanakan program pengampunan pajak sebagai bagian program fiskalnya. Beberapa negara melakukan pengulangan program pengampunan pajak, seperti contoh: Argentina, Perancis, India, Irlandia dan Italia menawarkan program pengampunan pajak beberapa kali dan kadang-kadang pengulangan dari program pengampunan pajak sebelumnya dengan interval waktu yang pendek seperti setiap 2 tahun. Hal yang senada disampaikan Le Borge and Baer (2008) dalam Marchese (2014) yang menyatakan bahwa setelah sekian tahun, pemerintah pusat dari negara-negara berkembang (misalnya: Argentina, Kolumbia, Brasil, India, Filipina dan Turki) menawarkan ulang program pengampunan pajak.

\section{KEBUTUHAN AKAN PROGRAM PENGAMPUNAN PAJAK}

Dalam melakukan pemungutan pajak, setiap pemerintah di suatu nega- ra akan menghadapi masalah kepatuhan wajib pajak untuk membayar pajak dengan baik dan benar sesuai dengan keadaan yang sesungguhnya. Banyak wajib pajak yang melakukan penghindaran untuk membayar pajak, baik dengan cara yang melanggar ketentuan pajak yang berlaku (tax evasion) maupun cara yang tidak melanggar ketentuan pajak yang berlaku (tax avoidance) berupa manuver-manuver dengan memanfaatkan kelemahan peraturan pajak yang berlaku.

Masalah kejahatan perpajakan telah menjadi masalah bersama otoritas perpajakan negara-negara di seluruh dunia. Berbagai cara dilakukan pemerintah negara-negara di seluruh dunia untuk memerangi kejahatan di bidang perpajakan. Penegakan hukum dengan memberikan sanksi hukum yang tegas dan keras berupa sanksi administrasi dan sanksi pidana kepada wajib pajak yang melakukan kecurangan terhadap pembayaran pajak telah dilakukan dalam rangka untuk memerangi kejahatan di bidang perpajakan.

Globalisasi telah membuka peluang yang lebih besar bagi para pelaku kejahatan perpajakan untuk memperluas cakupan daerah operasinya menjadi lintas negara. Dampaknya adalah kejahatan perpajakan yang sifatnya transnasional menjadi berkembang dengan memanfaatkan kesulitan otoritas perpajakan suatu negara dalam melakukan penelusuran informasi mengenai penghasilan dan harta wajib pajak yang berada dan berasal dari banyak negara. Sejalan dengan itu, maka kerjasama internasional pertukaran informasi wajib pajak antara otoritas pajak di satu negara dengan otoritas pajak di negara lain menjadi sangat penting untuk memerangi atau mena- 
ngani kejahatan perpajakan yang melibatkan banyak negara.

Mengingat semakin kompleksnya kejahatan di bidang perpajakan, maka proses penanganannya juga tidak dapat hanya mengandalkan satu instrumen tunggal saja, misalnya instrumen penegakan hukum yang keras bagi wajib pajak yang tidak patuh, tetapi harus melibatkan dan mengkolaborasi semua instrumen yang ada. Banyak negara di dunia menggunakan instrumen program pengampunan pajak dalam mengatasi masalah berkaitan dengan kepatuhan wajib pajak. Jika proses penegakan hukum bisa dianggap sebagai hard tax law enforcement, maka program pengampunan pajak dapat dikatakan sebagai soft tax law enforcement. Kedua-duanya bertujuan untuk meningkatkan kepatuhan wajib pajak, yang pada akhirnya diharapkan akan meningkatkan penerimaan negara dari sektor pajak.

\section{MANFAAT DARI PROGRAM PENGAMPUNAN PAJAK}

Menurut Marchese (2014) program pengampunan pajak dapat menjadi alat kebijakan pajak yang berguna ketika dieksploitasi dalam keadaan luar biasa. Pengampunan pajak juga dapat digunakan secara sistematis sebagai mekanisme diskriminatif untuk meningkatkan efisiensi atau bahkan ekuitas dari sistem pajak, tetapi hanya jika komitmen pemerintah untuk menegakkan hukum pajak kredibel/dapat dipercaya.

Mouloud (2015) menyatakan sebagian besar pemerintah di banyak negara menjalankan program pengampunan pajak untuk memerangi kejahatan perpajakan (tax evasion) dan menyesuaikan shadow economy serta meningkatkan pendapatan pajak untuk tujuan jangka pendek dan memperluas basis pajak untuk tujuan jangka panjang. Dalam jangka pendek menawarkan program pengampunan pajak dapat meningkatkan tingkat kepatuhan wajib pajak dengan bertambahnya wajib pajak dan nilai yang dapat dipajaki yang sebelumnya termasuk shadow economy (Mattiello, 2005). Kilonzo (2012) menyatakan banyak negara maju seperti halnya negara berkembang melaksanakan program pengampunan pajak sebagai bagian program fiskalnya untuk meningkatkan pertumbuhan pendapatannya.

Alm et al. (2007) menyatakan pendukung program pengampunan pajak menekankan adanya pendapatan pajak jangka pendek dan segera diperoleh dari program pengampunan pajak dan sering berpendapat bahwa penerimaan pajak di masa depan dapat meningkat, jika program pengampunan pajak dapat mendorong individu dan korporasi yang tidak berada di dalam daftar wajib pajak untuk menjadi wajib pajak dan memenuhi kewajiban perpajakannya, jika program pengampunan pajak disertai dengan layanan yang lebih baik kepada wajib pajak, pendidikan yang lebih baik mengenai tanggungjawab wajib pajak dan secara khusus penegakan hukum yang lebih ketat terhadap pelaku penghindaran membayar pajak.

Uchitelle (1989) menyatakan pemerintah yang mengimplementasikan program pengampunan pajak akan memperoleh pendapatan dari 3 sumber. Sumber pertama adalah jumlah besar pendapatan dari ekonomi domestik yang berasal dari penghasilan pajak yang belum dilaporkan karena berada pada underground economy. Program pengampunan pajak didesain tidak hanya untuk meningkatkan pen- 
dapatan pajak saat ini, tetapi juga untuk mengurangi secara permanen jumlah aktivitas ekonomi yang terjadi pada underground economy, oleh karenanya meningkatkan pendapatan pajak yang akan datang. Sumber kedua dari pendapatan potensial adalah dari flight capital. Pemerintah menggunakan program pengampunan pajak sebagai alat untuk menarik warga negara agar mau melakukan repatriasi sejumlah uangnya yang sering sangat besar dan telah dibawa ke luar negeri secara tidak legal. Kerugian pajak yang timbul karena uang yang dibawa ke luar negeri ini sangat substansial. Sumber ketiga dan terakhir dari pendapatan potensial adalah berasal dari pembayaran kembali pajak yang sebelumnya secara tidak disengaja telah dibayar lebih kecil dari seharusnya tetapi tidak pernah dilaporkan kesalahan ini karena khawatir dikenakan hukuman berhubungan dengan tax evasion. Program pengampunan pajak mendorong pembayaran kembali secara penuh dengan mengeliminasi atau mengurangi hukuman.

Kilonzo (2012) menyatakan semua program pengampunan pajak memerlukan elemen umum dari pengampunan yang dapat mempengaruhi hasil pendapatan dan perilaku pembayar pajak. Menurut Fox and Murray (2004) dalam Kilonzo (2012), tujuan dan sasaran dari program pengampunan pajak banyak, tetapi meningkatkan hasil pendapatan, memperluas basis pajak dan meningkatkan kepatuhan wajib pajak berada pada urutan teratas di daftar yang menunjukkan kekhawatiran pemerintah bahwa mereka gagal untuk menagih penghasilan pajak substansial yang terutang.

Dari uraian di atas ada banyak manfaat dari program pengampunan pajak. Namun ada beberapa manfaat yang menjadi harapan utama dari pemerintah negara-negara yang melaksanakan program pengampunan pajak, yaitu: (i) manfaat yang diharapkan dapat dicapai dalam jangka pendek adalah peningkatan penerimaan pajak, terutama biasanya untuk menutupi penurunan pendapatan pemerintah karena terjadinya krisis ekonomi/keuangan; (ii) manfaat jangka panjang adalah perluasan basis pajak yang pada akhirnya diharapkan dapat menigkatkan penerimaan pajak dalam jangka panjang; (iii) untuk menarik dana milik wajib pajak yang ditempatkan di luar negeri (repatriasi); (iv) untuk meningkatkan kepatuhan wajib pajak serta mengurangi kejahatan di bidang perpajakan (tax evasion); (v) mengurangi jumlah pelaku ekonomi dan bisnis yang saat ini berada dalam kelompok shadow ecnomy. (vi) menciptakan suatu budaya membayar pajak secara suka rela dan berkelanjutan.

\section{DAMPAK NEGATIF PROGRAM PENGAMPUNAN PAJAK}

Menurut Nar (2015) praktek pengampunan pajak merupakan situasi yang menggembirakan dan diinginkan dalam hal ekonomi untuk orang-orang yang mendapatkan manfaat dari adanya peraturan pengampunan pajak. Situasi ini dianggap tidak adil bagi sebagian orang, karena pembayar pajak yang jujur berpikir bahwa penerimaan pajak yang hilang dengan adanya program pengampunan pajak akan menyebabkan target penerimaan pajak pemerintah periode yang akan datang meningkat untuk menutupi penerimaan pajak yang hilang dari dilaksanakannya program pengampunan pajak, dan bagi wajib pajak yang jujur ini akan berarti menambah beban pajak 
mereka yang akan datang menjadi lebih berat.

Uchitelle (1989) menyatakan manfaat dari program pengampunan pajak harus ditimbang terhadap sejumlah kerugian yang potensial terjadi. Program pengampunan pajak dapat memiliki efek insentif yang tidak diinginkan jika mereka sering diimplementasikan. Program pengampunan pajak juga mungkin mempunyai pengaruh menghukum wajib pajak yang secara rutin membayar pajak dengan baik. Efek negatif lain dari implementasi program pengampunan pajak adalah adanya kesan bahwa pemerintah tidak mempunyai kemampuan untuk melakukan penegakan hukum kepada wajib pajak yang melakukan kecurangan pembayaran pajak dan ini akan menurunkan kredibiltas pemerintah. Di samping itu pemerintah yang melakukan program pengampunan pajak cenderung untuk tidak menguji kembali peraturan yang memberatkan dan kebijakan ekonomi buruk yang sering merupakan akar penyebab penggelapan pajak.

Ross and Buckwalter (2012) menyatakan program pengampunan pajak dapat juga meningkatkan tingkat ketidakpatuhan di kalangan wajib pajak yang menyimpulkan bahwa program pengampunan pajak merupakan fenomena berulang. Pemikiran ini mungkin dapat membuat wajib pajak berpandangan dari pada wajib pajak patuh membayar pajak sesuai dengan ketentuan yang berlaku akan lebih baik bila wajib pajak melakukan kecurangan membayar pajak saat ini yang nantinya juga dapat diampuni melalui program pengampunan pajak yang dilaksanakan pemerintah secara berkala dan berulang. Dengan demikian wajib pajak akan mendapatkan banyak keuntungan, mengingat program pengampunan pajak memberikan banyak keringanan berupa penghapusan sanksi administrasi, sanksi pidana dan juga pengenaan tarif yang lebih rendah dari pada tarif normal. Efek negatif dari program pengampunan pajak menurut Alm et al. (2007) adalah wajib pajak yang jujur akan marah dengan adanya perlakuan istimewa bagi para wajib pajak yang melakukan penghindaran membayar pajak dan jika individuindividu percaya bahwa program pengampunan pajak bukan merupakan kesempatan yang hanya satu kali saja. Bayer et al. (2015) menyatakan manfaat dari program pengampunan pajak bagi wajib pajak adalah menunda pembayaran sebagian kewajiban perpajakannya dengan cara melaporkan penghasilannya yang lebih rendah dari pada yang sebenarnya, dan kemudian sisanya akan dibayar melalui deklarasi penghasilan pada saat program pengampunan pajak dilaksanakan. Mettiello (2005) menyatakan di lain sisi untuk jangka panjang, program pengampunan pajak mungkin melemahkan kemauan wajib pajak untuk memenuhi kewajibannya. İpek et al. (2012) menyatakan program pengampunan pajak memang menggandakan pendapatan pemerintah dalam jangka pendek, tetapi akan mengurangi pendapatan dalam jangka panjang. Program pengampunan pajak mendorong penggelapan pajak (tax evasion), menggoyang kepercayaan kepada pemerintah, mengurangi tingkat kepatuhan wajib pajak dan program pengampunan pajak seharusnya tidak diterapkan.

Dari uraian di atas, nampak bahwa program pengampunan pajak di samping memberikan banyak manfaat bagi pemerintah dari negara-negara 
yang melaksanakan, juga memiliki dampak negatif, antara lain adalah: (i) program pengampunan pajak sering dianggap oleh para wajib pajak patuh merupakan program yang memberikan perlakuan diskriminasi terhadap mereka; wajib pajak patuh telah melaksanakan kewajibannya membayar pajak secara baik dan benar, tetapi tidak mendapatkan penghargaan apaapa; sebaliknya wajib pajak yang melakukan penghindaran pajak diberikan berbagai fasilitas keringanan pajak berupa pembebasan sanksi pidana, sanksi administrasi, pengenaan tarif pajak yang lebih rendah dari tarif normal dan fasilitas keringanan pajak lainnya melalui program pengampunan pajak; wajib pajak patuh beranggapan para wajib pajak yang melakukan penghindaran pembayaran pajak yang jelas-jelas telah bersalah tidak membayar pajak dengan benar seharusnya diberikan hukuman (punishment), tetapi malah diberi berbagai fasilitas keringanan pajak (reward) melalui program pengampunan pajak; para pelaku penghindaran membayar pajak seolaholah diberi "karpet merah", sedangkan para wajib pajak patuh tidak mendapatkan penghargaan (reward) apa-apa; hal ini dapat mendorong wajib pajak yang semula patuh menjadi tidak patuh, karena merasa diperlakukan diskriminatif dan tidak adil; (ii) apabila program pegampunan pajak ini dilakukan lebih dari 1 kali, apalagi cenderung sering dilakukan dan bersifat rutin/reguler setiap jangka waktu tertentu, misalkan 5 tahun sekali, maka tingkat kepatuhan wajib pajak cenderung akan menurun; wajib pajak beranggapan apabila saat ini mereka melakukan kesalahan atau penghindaran membayar pajak, maka nanti saat pemerintah melaksanakan program peng- ampunan pajak, kesalahan mereka akan diampuni melalui program pengampunan pajak; mereka malah merasa akan lebih diuntungkan bila mereka menjadi wajib pajak yang tidak patuh dibandingkan wajib pajak patuh; (iii) timbulnya kesan bahwa pemerintah tidak mampu untuk menerapkan penegakan hukum yang baik agar wajib pajak patuh membayar pajak dan harus menggunakan program pengampunan pajak untuk menghimbau wajib pajak yang tidak patuh agar menjadi patuh; hal ini dapat menjatuhkan wibawa pemerintah di mata masyarakat, khususnya wajib pajak; (iv) pemerintah yang mengadakan program pengampunan pajak biasanya sangat mengandalkan program ini untuk meningkatkan pendapatan dari pajak dan kepatuhan wajib pajak, sehingga mereka lupa untuk melakukan evaluasi lebih lanjut terhadap faktor-faktor lain yang mungkin mempengaruhi keinginan wajib pajak untuk membayar pajak dengan baik dan benar yang mungkin tidak bisa diselesaikan hanya dengan dilaksanakannya program pengampunan pajak; faktor-faktor tersebut bisa berupa peraturan perpajakan yang memberatkan, susah dipahami dan atau kebijakan ekonomi yang buruk.

\section{PROGRAM PENGAMPUNAN PAJAK YANG BAIK}

Program pengampunan pajak yang diimplementasikan oleh pemerintah di suatu negara pada dasarnya mempunyai manfaat dan bertujuan untuk meningkatkan penerimaan dari sektor pajak baik untuk jangka pendek maupun jangka panjang. Namun perlu disadari bahwa pelaksanaan program pengampunan pajak juga mempunyai dampak negatif yang harus diantisipasi oleh pemerintah agar pelaksanaan pro- 
gram pengampunan pajak dapat berhasil dan mencapai tujuan yang diinginkan.

Menurut Uchitelle (1989) program pengampunan pajak dapat berhasil, hanya jika program ini dirasakan sebagai suatu program yang unik, tidak berulang dan hanya dilaksanakan satu kali saja. Hanya jika individu melihat program pengampunan pajak sekali saja untuk memperbaiki pelanggaran di masa lampau yang mungkin membuat program ini menjadi efektif. Program pengampunan pajak yang dilakukan secara berulang tidak hanya menghapus insentif untuk melaporkan pajak terhutang yang tidak dilaporkan, tetapi juga dalam banyak kasus meningkatkan frekuensi penggelapan pajak. Bose and Jetter (2010) menyatakan kebanyakan tulisan setuju bahwa program pengampunan pajak yang dilaksanakan satu kali saja dan waktunya yang tidak dapat diantisipasi disertai dengan perubahan dalam sistem pajak secara umum, kelihatannya mempunyai kesempatan yang besar untuk sukses, di mana tingkat kesuksesannya kebanyakan dilihat dari pendapatan yang dihasilkan dan tingkat kepatuhan wajib pajak, baik jangka pendek maupun jangka panjang. Mattiello (2005) menyatakan untuk menghindari bahwa program pengampunan pajak mungkin mengarah pada penurunan tingkat kepatuhan, maka penting dan mutlak dikondisikan agar wajib pajak tidak dapat mengantisipasi adanya program pengampunan pajak. Karena jika wajib pajak dapat mengantisipasi adanya program pengampunan pajak yang akan diimplementasikan oleh pemerintah dan wajib pajak juga dapat mengantisipasi waktu pelaksanaannya, maka penggelapan pajak ( $\operatorname{tax}$ evasion) akan meningkat. Alm et al.
(2007) menemukan bahwa program pengampunan pajak yang dilaksanakan beberapa kali (multiple tax amnesties) di Rusia mempunyai pengaruh yang kecil terhadap pendapatan baik untuk jangka pendek maupun jangka panjang. İpek et al. (2012) menyatakan program pengampunan pajak harus diterapkan hanya satu kali saja. Tetapi wajib pajak yang mendapatkan manfaat dari program pengampunan pajak akan bersikap sebaliknya. Mereka menginginkan program pengampunan pajak dilaksanakan lebih dari satu kali.

Menurut Mikesell (1986) dalam Marchese (2014) waktu pelaksanaan program pengampunan pajak merupakan hal kunci dalam implementasinya, seperti: berapa lama waktu yang disediakan untuk pelaksanaan program, apakah ada perpanjangan waktu yang diberikan atau tidak, frekuensi program akan dilaksanakan, yang mana kesemuanya jelas mempengaruhi keberhasilan pelaksanaan program pengampunan pajak. Torgler et al. (2003) dalam Kilonzo (2012) menemukan bahwa program pengampunan pajak di masa mendatang yang dapat diantisipasi mempunyai pengaruh negatif terhadap tingkat kepatuhan wajib pajak.

Pelaksanaan program pengampunan pajak dari beberapa negara menunjukkan bahwa ada negara yang dapat sukses menerapkannya, tetapi ada pula negara yang tidak berhasil dalam mengimplementasikannya. Pengalaman dari beberapa negara dalam mengimplementasikan program pengampunan pajak menurut Uchitelle (1989) dan Mouloud (2015) dapat diuraikan sebagai berikut:

a. Irlandia

Pemerintah Irlandia melaksanakan program pengampunan pajak yang dilaksanakan untuk periode waktu 
10 bulan pada tahun 1988 yang dapat menghasilkan tambahan pendapatan sebesar US\$ 750 juta dari jumlah US\$ 50 yang ditargetkan. Program pengampunan pajak ini baru dilaksanakan pertama kali dan dinyatakan sebagai program pengampunan pajak yang terakhir. Program ini diimplementasikan dengan disertai serangkaian langkahlangkah lain untuk mendukungnya, antara lain: (i) meningkatkan jumlah "tax sheriffs" yang bertanggungjawab melaksanakan penagihan pajak; (ii) mempublikasikan pada surat kabar nasional daftar nama wajib pajak yang nakal dalam pembayaran pajak; (iii) pada akhir periode program pengampunan pajak, pemerintah memperkenalkan sistem perpajakan baru, yang memperberat sanksi bagi wajib pajak yang nakal dan memberikan tambahan kewenangan kepada otoritas pajak untuk menyita saham, aset lainnya dan membekukan rekening bank dari wajib pajak yang menghindari pembayaran pajak. Salah satu faktor yang mungkin dianggap mengurangi sukses untuk meningkatkan pendapatan pajak masa yang akan datang adalah pemerintah tidak melakukan penurunan tarif pajak atau memperluas pengecualian pengenaan pajak. Setelah sukses dengan program pengampunan pajak tahun 1988, Pemerintah Irlandia kemudian melaksanakan program pengampunan pajak lagi pada tahun 1993, tetapi hasilnya tidak sesukses yang dilaksanakan pada tahun 1988. Hal ini memberikan suatu konfirmasi bahwa program pengampunan pajak yang dilaksanakan lebih dari 1 kali tidak akan mampu memberikan keberhasilan seperti yang diharapkan.

b. India

Pemerintah India melaksanakan program pengampunan pajak pada tahun 1981 yang merupakan program kelima dari serangkaian program pengampunan pajak yang ditawarkan Pemerintah India dalam periode 12 tahun. Program ini diberlakukan untuk jangka waktu selama 3 bulan. Program pengampunan pajak ini dilaksanakan dengan cara Pemerintah India menerbitkan obligasi khusus dengan jatuh tempo selama 10 tahun. Setiap orang dan badan dapat membeli obligasi ini dengan menggunakan dana yang tidak akan dipertanyakan asal-usulnya, termasuk apabila dana tersebut berasal dari pasar gelap. Dana tersebut beserta bunganya tidak akan dikenakan Pajak Kekayaan dan Pajak Penghasilan pada saat jatuh temponya. Dari penerbitan obligasi ini Pemerintah India dilaporkan berhasil menarik dana lebih dari US\$ 10 milyar. Walaupun dalam jangka pendek pendapatan yang diperoleh dari program pengampunan pajak ini cukup besar, namun program ini belum mampu untuk memperluas basis pajak secara keseluruhan. Pelaksanaan program pengampunan pajak yang dilakukan tidak dibarengi dengan penguatan melalui perubahan hukum pajak dan perubahan struktural pada sistem pajak serta mekanisme penegakan hukum pajak masih sama dengan yang lalu.

c. Belgia

Pemerintah Belgia melaksanakan program pengampunan pajak pada tahun 1984 dengan tujuan menarik 
flight capital (modal yang lari ke luar negeri) dan membawa danadana yang berasal dari pasar gelap ke aktivitas ekonomi dan bisnis formal/terbuka. Program pengampunan pajak ini memberikan pengecualian pengenaan pajak atas modal yang diinvestasikan untuk aktivitas yang menggunakan tenaga kerja banyak dalam periode yang berakhir pada akhir tahun 1984. Wajib pajak yang mengikuti program pengampunan pajak ini dibebaskan dari kewajiban untuk melaporkan asal-usul dana, asalkan $1 / 11$ atau $9 \%$ dari jumlah dana diinvestasikan pada sertifikat non interest bearning treasury dalam jangka waktu 5 tahun. Namun karena ada masalah yang berkaitan dengan politik pada tahun 1985, Pemerintah Belgia terpaksa membatalkan Undang-Undang tentang pengampunan pajak ini. Kemudian pada tahun 2004 diadakan program pengampunan pajak lagi dengan tujuan untuk mendukung pertumbuhan melalui pemulihan modal dan investasi di sektor informal dan dinyatakan tujuannya adalah menciptakan 200.000 pekerjaan serta mendapatkan tambahan pendapatan untuk membiayai operasional pemerintahan.

d. Argentina

Pada tahun 1987, Argentina melaksanakan program pengampunan pajak yang terutama ditujukan untuk mengembalikan modal yang lari ke luar negeri dengan program yang disebut program debt to equity. Wajib pajak yang mengikuti program ini diharuskan menyediakan dana pendamping untuk setiap utang yang dikonversi. Dana pendamping ini tidak akan diusut asal-usulnya. Dana dari utang dan dana pendamping ini harus digunakan untuk investasi seperti membeli mesin baru, membangun pabrik baru atau meningkatkan kapasitas fisik dari fasilitas yang sudah ada. Pengembalian dana pendamping ini tidak dikenakan pajak. Namun program pengampunan pajak yang dilaksanakan ini gagal, karena tidak didukung instrumen lainnya, seperti perubahan aturan perpajakan dan perubahan kebijakan di bidang ekonomi dan keuangan. Tidak adanya stimulus dan deregulasi di bidang ekonomi dan keuangan menyebabkan pelarian modal ke luar negeri tetap berlangsung.

e. Kolumbia

Kolumbia melaksanakan program pengampunan pajak pada tahun 1987. Program pengampunan pajak ini memberikan kesempatan kepada wajib pajak yang belum melaporkan semua atau sebagian aset bersihnya (selisih nilai aset dengan kewajiban), dengan cara melakukan pembetulan tanpa dikenai sanksi atau menjadi subjek dari pemeriksaan pajak dengan syarat wajib pajak tidak sedang diperiksa oleh otoritas pajak serta nilai aset bersih yang dilaporkan kembali harus lebih besar dari pada yang sudah dilaporkan sebelumnya. Untuk menunjukkan kesungguhan dalam melaksanakan program pengampunan pajak ini, di saat yang bersamaan pemerintah juga mengeluarkan perubahan peraturan perpajakan yang berhubungan dengan penyatuan tarif pajak korporasi, penurunan tarif pajak untuk orang pribadi, mengeliminasi pengenaan pajak ganda untuk di- 
viden dan menaikkan tarif pajak penghasilan yang dipotong/dipungut. Program pengampunan pajak yang diikuti dengan perubahan terhadap peraturan perpajakan telah memberikan dukungan suksesnya program pengampunan pajak yang dilaksanakan oleh Pemerintah Kolombia. Peningkatan pendapatan yang terjadi tahun 1987 berlanjut pada tahun 1988 sebagai dampak perluasan basis pengenaan pajak.

f. Perancis

Pemerintah Perancis mengadakan program pengampunan pajak pada tahun 1982 dengan tujuan mendorong wajib pajak untuk melakukan repatriasi dananya yang berada di luar negeri. Namun program pengampunan pajak ini gagal, karena wajib pajak walaupun diberi keringanan tarif pajak penghasilan untuk repatriasi, tapi masih dikenakan pajak kekayaan dengan tarif yang tinggi. Program pengampunan pajak ini dilakukan kembali pada tahun 1986 dengan tujuan yang sama. Dengan program pengampunan pajak ini repatriasi dana dari luar negeri hanya dikenakan tarif pajak penghasilan sebesar $10 \%$, jauh lebih rendah dibandingkan dengan tarif normal pajak penghasilan. Di samping itu Pemerintah Perancis juga menghapuskan pengenaan pajak kekayaan bagi wajib pajak yang mengikuti program ini. Pengalaman Pemerintah Perancis ini sekali lagi menunjukkan bahwa program pengampunan pajak tidak bisa dilaksanakan sebagai program yang berdiri sendiri saja, tetapi harus didukung dengan instrumen, program atau kebijakan struktural lainnya.

\section{PROGRAM PENGAMPUNAN PAJAK DI INDONESIA}

Di Indonesia pemungutan pajak dilakukan oleh Direktorat Jenderal Pajak yang berada di bawah Kementerian Keuangan. Sejak reformasi perpajakan dilakukan pada tahun 1983, Direktorat Jenderal Pajak telah beberapa kali melaksanakan program yang diberi nama sunset policy. Melalui program ini Direktorat Jenderal Pajak memberikan keringanan penghapusan sanksi perpajakan kepada wajib pajak yang dengan suka rela melakukan pembetulan/perbaikan atas kesalahan penyampaian data penghasilan dan biaya yang dilaporkan dalam Surat Pemberitahuan Tahunan Pajak Penghasilan. Program yang telah dilaksanakan ini bukan merupakan program pengampunan pajak yang diimplementasikan oleh banyak negara, tetapi hanya merupakan bagian dari kebijakan dari Direktorat Jenderal Pajak dalam rangka meningkatkan penerimaan dari sektor pajak yang menjadi tugasnya. Program ini juga tidak pernah memberikan jaminan bahwa tindakan kejahatan atau manipulasi perpajakan yang mungkin pernah dilakukan wajib pajak di masa yang lalu tidak akan diusut dan ditindaklanjuti, jika berpartisipasi dalam program ini. Karena itu untuk melaksanakan program sunset policy tidak pernah dibuat suatu Undang-Undang khusus, tetapi cukup menggunakan acuan Undang-Undang Perpajakan yang sudah ada dan pelaksanaan program ini merupakan bagian dari kewenangan Direktorat Jenderal Pajak untuk memberikan keringanan sanksi perpajakan kepada wajib pajak.

Pada tahun 2016 Pemerintah Indonesia melaksanakan program pe- 
ngampunan pajak yang berlaku mulai tanggal 1 Juli 2016 dan berakhir pada tanggal 31 Maret 2017. Pelaksanaan program pengampunan pajak dilakukan dengan berpedoman pada UndangUndang Nomor 11 Tahun 2016 tentang Pengampunan Pajak dan peraturan pelaksana lainnya. Wajib pajak yang mengikuti program pengampunan akan dihapus pajaknya yang belum atau kurang dibayar pada masa lalu, tidak dikenai sanksi administrasi perpajakan dan sanksi pidana di bidang perpajakan. Wajib pajak yang mengikuti program pengampunan pajak ini harus mengungkapkan/mendeklarasikan tambahan harta bersihnya (total tambahan harta dikurangi dengan tambahan hutang) dan membayar uang tebusan yang dihitung dengan mengalikan tarif uang tebusan dengan nilai tambahan harta bersih. Deklarasi harta itu dilakukan oleh wajib pajak dengan membuat pernyataan tentang harta bersih yang dimiliki, harta bersih yang telah dilaporkan dalam Surat Pemberitahuan Tahunan Pajak Penghasilan terakhir (tahun 2015) dan tambahan harta bersih yang belum dilaporkan dalam Surat Pemberitahuan Tahunan Pajak Penghasilan terakhir (tahun 2015). Ada beberapa tarif uang tebusan yang diberlakukan, yaitu: (i) untuk wajib pajak yang mendeklarasikan tambahan harta di dalam negeri akan dikenakan 3 macam tarif, yaitu $2 \%$, $3 \%$ dan $5 \%$. Tarif uang tebusan $2 \%$ akan dikenakan bagi wajib pajak yang menyampaikan surat pernyataan pada periode kesatu (1 Juli 2016 sampai dengan 30 September 2016); sedangkan tarif uang tebusan 3\% akan dibebankan kepada wajib pajak yang yang menyampaikan surat pernyataan pada periode kedua (1 Oktober 2016 sampai dengan 30 Desember 2016); kemudian tarif uang tebusan 5\% akan dikenakan bagi wajib pajak yang menyampaikan surat pernyataan pada periode ketiga (1 Januari 2017 sampai dengan 31 Maret 2017); (ii) untuk wajib pajak yang mendeklarasikan tambahan harta di luar negeri dan tidak direpatriasi ke dalam negeri akan dikenakan 3 macam tarif, yaitu $4 \%, 6 \%$ dan $10 \%$. Tarif uang tebusan $4 \%$ akan dikenakan bagi wajib pajak yang menyampaikan surat pernyataan pada periode kesatu (1 Juli 2016 sampai dengan 30 September 2016); sedangkan tarif uang tebusan 6\% akan dibebankan kepada wajib pajak yang yang menyampaikan surat pernyataan pada periode kedua (1 Oktober 2016 sampai dengan 30 Desember 2016); kemudian tarif uang tebusan $10 \%$ akan dikenakan bagi wajib pajak yang menyampaikan surat pernyataan pada periode ketiga (1 Januari 2017 sampai dengan 31 Maret 2017); (iii) untuk wajib pajak yang mendeklarasikan tambahan harta di luar negeri dan direpatriasi ke dalam negeri akan dikenakan 3 macam tarif, yaitu $2 \%, 3 \%$ dan $5 \%$. Tarif uang tebusan $2 \%$ akan dikenakan bagi wajib pajak yang menyampaikan surat pernyataan pada periode kesatu (1 Juli 2016 sampai dengan 30 September 2016); sedangkan tarif uang tebusan 3\% akan dibebankan kepada wajib pajak yang yang menyampaikan surat pernyataan pada periode kedua (1 Oktober 2016 sampai dengan 30 Desember 2016); kemudian tarif uang tebusan 5\% akan dikenakan bagi wajib pajak yang menyampaikan surat pernyataan pada periode ketiga (1 Januari 2017 sampai dengan 31 Maret 2017); (iv) khusus untuk wajib pajak yang tergolong UMKM (Usaha Mikro, Kecil dan Menengah), yaitu wajib pajak dengan peredaran usaha 
pada tahun terakhir sampai dengan Rp. 4.800.000.000,- akan dikenakan tarif uang tebusan sebesar $0,5 \%$ jika harta yang diungkapkan sampai dengan $\mathrm{Rp}$. 10.000.000.000,-, dan tarif uang tebusan $2 \%$ bila harta yang diungkapkan lebih dari Rp. 10.000.000.000,-. Jenis pajak yang diberi pengampunan dengan membayar uang tebusan ada 3, yaitu: Pajak Penghasilan, Pajak Pertambahan Nilai (PPN) dan Pajak Penjualan atas Barang Mewah (PPnBM). Nilai tambahan hutang yang dapat dikurangkan dari nilai tambahan harta untuk menghitung nilai tambahan harta bersih untuk wajib pajak badan nilai hutang dibatasi $75 \%$ dari nilai tambahan harta dan untuk wajib pajak orang pribadi nilai hutang dibatasi $50 \%$ dari nilai tambahan harta. Harta yang direpatriasi harus diinvestasikan di dalam negeri paling sedikit 3 tahun.

Program pengampunan pajak ini dapat diikuti oleh semua wajib pajak: badan, orang pribadi, pengusaha dengan omzet tertentu dan wajib pajak yang belum mempunyai Nomor Pokok Wajib Pajak (NPWP). Wajib pajak yang tidak diperbolehkan untuk mengikuti program pengampunan pajak ini adalah wajib pajak yang sedang dilakukan penyidikan dan berkas penyidikannya telah dinyatakan lengkap oleh kejaksaan, wajib pajak yang sedang mengikuti proses peradilan atau wajib pajak yang sedang menjalani hukum pidana. Semuanya berhubungan dengan tindak pidana di bidang perpajakan.

Program pengampunan pajak yang dilaksanakan ini mempunyai tujuan: (i) meningkatkan angka pertumbuhan ekonomi dengan adanya sumber pertumbuhan ekonomi baru melalui repatriasi harta; repatriasi harta ini akan meningkatkan likuiditas domestik, per- baikan nilai tukar rupiah, suku bunga yang kompetitif, peningkatan investasi; (ii) memperluas basis data perpajakan dalam rangka untuk mendapatkan data yang lebih valid, komprehensif dan terintegrasi, sehingga potensi penerimaan pajak dapat dihitung lebih reliable; (iii) meningkatkan penerimaan pajak baik untuk jangka pendek melalui penerimaan uang tebusan maupun untuk jangka panjang melalui perluasan basis pemajakan.

\section{EVALUASI KEMUNGKINAN KEBERHASILAN PROGRAM PENGAMPUNAN PAJAK DI INDONESIA}

Program pengampunan pajak dapat dikatakan sebagai suatu program kontroversial yang dilaksanakan oleh pemerintah di banyak negara, karena program ini memberikan reward kepada wajib pajak yang tidak patuh dan telah melakukan penghindaran pajak melalui penghapusan sanksi, pemberian tarif pajak yang lebih rendah dan bentuk keringanan lainnya, yang mana hal ini tidak diberikan kepada wajib pajak yang telah melaksanakan kewajiban perpajakannya dengan baik dan benar. Jadi program ini dianggap tidak adil dan terlalu memihak, karena wajib pajak yang tidak patuh seharusnya diberikan hukuman (punishment) bukan diberikan reward. Sedangkan wajib pajak patuh yang seharusnya diberikan reward. Pendapatan para ahli mengenai perlu tidaknya program pengampunan pajak dilaksanakan juga berbeda-beda. Ada yang mendukung pelaksanaan program ini yang diyakini memberikan banyak manfaat bagi pemerintah, tetapi ada juga yang menentang dilaksanakannya program ini dengan berbagai pertimbangan. Namun secara umum jumlah ahli yang mendu- 
kung pelaksanaan program pengampunan pajak lebih banyak dari pada yang menentang. Secara umum dapat dikatakan walaupun ada berbagai kekurangan/kelemahan dan dampak negatif, tetapi program pengampunan pajak ini diyakini masih sangat bermanfaat bila diaplikasikan dengan cara yang tepat dan dalam situasi dan kondisi yang tepat pula.

Program pengampunan pajak yang dilaksanakan oleh Pemerintah Indonesia baru pertama kali dilaksanakan dan dinyatakan hanya diimplementasikan satu kali saja dan tidak ada rencana untuk diadakan kembali. Jadi program pengampunan pajak yang dilaksanakan tergolong single tax amnesty, bukan multipe tax amnesty. Program pengampunan pajak semacam ini menurut Uchitelle (1989) merupakan program yang unik, hanya dilaksanakan 1 kali saja, program pengampunan pajak yang pertama sekaligus yang terakhir (the first and the last tax amnesty program). Program pengampunan pajak yang dilakukan ini bukan merupakan program yang berdiri sendiri, tetapi akan diikuti dengan perbaikan di dalam sistem perpajakan dan penegakan hukum yang lebih ketat ke depannya yang akan dilakukan melalui perubahan Undang-Undang Perpajakan pasca periode program pengampunan pajak berakhir. Agar program ini dapat dipahami dan dimengerti oleh masyarakat secara baik dan benar serta tidak menimbulkan persepsi yang salah di masyarakat, maka pemerintah telah melakukan sosialisasi besar-besaran mengenai pelaksanaan program ini. Sosialisasi ini tidak hanya melibatkan pejabat di Direktorat Jenderal Pajak, tetapi melibatkan semua aparat yang berkaitan dengan bidang ekonomi dan keuangan. Bahkan Bapak
Presiden Joko Widodo juga ikut turun melakukan sosialisasi. Berbagai media baik media cetak maupun media elektronik dan media sosial digunakan sebagi media sosialisasi.

Program pengampunan pajak yang dilaksanakan oleh Pemerintah Indonesia ini seharusnya diyakini sukses dalam implementasinya, karena beberapa pertimbangan: (i) program pengampunan pajak yang dilaksanakan merupakan single tax amnesty, hanya diimplementasikan 1 kali saja dan tidak ada rencana akan dilaksanakan lagi di kemudian hari (the first and the last tax amnesty program), sehingga wajib pajak tidak mempunyai harapan dan tidak mengantisipasi adanya program pengampunan pajak lagi di kemudian hari. Program pengampunan pajak seperti ini diyakini akan berhasil dalam pelaksanaannya (Uchitelle, 1989; Torgler et al. (2003) dalam Kilonzo (2009); Mattiello, 2005; Alm et al., 2007; İpek et al., 2012); (ii) program pengampunan pajak ini disosialisasikan secara besar-besaran melalui berbagai media, sehingga dapat menjangkau ke seluruh lapisan masyarakat; pengalaman dari beberapa negara menunjukkan sosialisasi besar-besaran akan mampu meningkatkan partisipasi masyarakat yang ikut dalam program pengampunan pajak ini; (iii) program pengampunan pajak ini mendapat dukungan politik yang kuat dari semua kekuatan politik yang ada dan periode suksesi kepemimpinan eksekutif dan legilatif nasional yang relatif masih lama (3 tahun lagi) menyebabkan kemungkinan terjadinya pembatalan Undang-Undang Pengampunan Pajak seperti di Belgia karena adanya masalah politik tidak akan terjadi di Indonesia; (iv) di samping mendapat dukungan politik yang kuat program 
pengampunan pajak ini juga mendapat dukungan yang kuat dari seluruh lapisan masyarakat, sehingga pelaksanaan program pengampunan pajak ini tidak akan membuat pemerintah kehilangan kredibilitasnya di masyarakat; (v) program pengampunan pajak ini memberikan insentif tarif uang tebusan khusus bagi pengusaha yang tergolong Usaha Mikro, Kecil dan Menengah (UMKM) yang diharapkan dapat menarik banyak pengusaha yang termasuk Usaha Mikro, Kecil dan Menengah (UMKM) yang sebelumnya berada di bawah payung shadow economy untuk migrasi ke kegiatan ekonomi dan bisnis yang formal; (vi) pemerintah telah memberikan sinyal bahwa pasca berakhirnya periode pengampunan pajak akan dilakukan perubahan Undang-Undang Perpajakan yang akan memberikan kewenangan lebih besar kepada otoritas pajak untuk melakukan penegakan hukum.

Menunjuk uraian di atas, maka diprediksi jumlah wajib pajak yang terlibat dalam program pengampunan pajak ini sangat besar, khususnya pada periode pertama yang berlangsung mulai 1 Juli 2016 sampai dengan 30 September 2016. Hal ini mengingat bahwa insentif tarif uang tebusan pada periode ini sangat menarik, karena tarif uang tebusannya paling kecil dibanding dengan periode kedua dan periode ketiga.

Wajib pajak, khususnya wajib pajak yang sebelumnya tidak melaksanakan kewajiban perpajakannya dengan baik dan benar akan tertarik untuk berpartisipasi mengikuti program pengampunan pajak ini. Bagi mereka program pengampunan pajak ini sangat menguntungkan. Dengan mengikuti program ini, kesalahan yang telah dilakukan di masa lalu dalam memenuhi kewajiban perpajakannya diampuni, dengan membayar uang tebusan yang sangat kecil tarifnya. Jika mereka tidak mengikuti program ini, maka ke depan kesalahan ini tidak dapat diperbaiki lagi dan bila otoritas pajak melakukan penegakan hukum yang lebih ketat dan tegas pasca periode program pengampunan pajak, maka sanksi yang dihadapi akan menjadi sangat berat.

Warga negara yang sebelum ini belum menjadi wajib pajak akan tertarik untuk mendaftarkan diri menjadi wajib pajak dan mengikuti program pengampunan pajak. Karena dengan demikian, penghasilan yang diperolehnya selama belum menjadi wajib pajak, belum pernah dilaporkan dan belum dibayar pajaknya secara otomatis akan diampuni dan tidak diusut kembali dengan hanya membayar uang tebusan dengan tarif yang sangat kecil. Hal ini sangat menguntungkan bagi mereka, karena jika mereka tetap tidak menjadi wajib pajak, tidak melaporkan penghasilannya dan tidak membayar pajak, maka apabila pasca berakhirnya periode pengampunan pajak, Direktorat Jenderal Pajak melakukan penegakan hukum yang lebih ketat dan lebih keras, mereka akan menanggung beban pajak beserta berbagai sanksi yang sangat memberatkan, karena adanya penegakan hukum ini.

Dengan banyaknya wajib pajak dan warga negara yang belum menjadi wajib pajak terlibat dalam program pengampunan pajak ini, maka konsekwensi logisnya adalah: pertama, jumlah peserta yang berpartisipasi dalam program ini sangat besar dan ini akan berpengaruh pada peningkatan kepatuhan wajib pajak; warga negara yang sebelumnya belum menjadi wajib pajak dan tidak patuh membayar pajak 
sudah termovitasi untuk migrasi menjadi wajib pajak sekaligus mulai patuh memenuhi kewajiban perpajakannya; wajib pajak yang belum sepenuhnya memenuhi kewajiban perpajakannya dengan mengikuti program pengampunan pajak ini akan menjadi lebih patuh, karena sumber-sumber penghasilan lain yang sebelumnya tidak pernah diungkapkan, melalui program pengampunan pajak sudah diungkapkan semuanya dan ke depannya penghasilan dan pajak yang dibayar akan meningkat dengan sendirinya; kedua, banyaknya wajib pajak yang terlibat dalam program pengampunan pajak ini akan menyebabkan penerimaan pajak untuk jangka pendek meningkat dengan tajam dari adanya uang tebusan program pengampunan pajak; ketiga, banyaknya pihak yang berpartisipasi, dalam program pengampunan pajak ini baik dari yang sudah menjadi wajib pajak maupun dari warga negara yang sebelumnya belum menjadi wajib pajak akan menyebabkan basis pengenaan pajak di masa yang akan datang meningkat dan ini berarti akan meningkatkan penerimaan pajak untuk jangka panjang; keempat, walaupun pihak yang ikut berpartisipasi dalam pengampunan pajak ini diestimasi sangat banyak, namun diprediksi sebagian besar hanya terlibat dalam deklarasi asetnya yang berada di dalam negeri, sedangkan yang memiliki aset di luar negeri kemungkinan hanya sebagian kecil yang melakukan repatriasi, sebagian kecil lagi hanya melakukan deklarasi, sedangkan lainnya sebagian besar tidak melakukan repatriasi maupun deklarasi; hal ini mungkin karena mereka beranggapan Direktorat Jenderal Pajak terlalu sulit untuk menelusuri keberadaan aset mereka di luar negeri yang sebagian besar berada di negara tax heaven yang mempunyai berlapislapis tameng untuk melindungi kerahasiaan keberadaan kepemilikan aset tersebut; perlu pula dipahami bahwa yang bisa direpatriasi hanya berupa aset lancar, sedangkan aset yang berupa aset tetap dan aset tidak bergerak agak susah untuk direpatriasi; di samping itu biasanya regulasi hukum di negara di mana aset tersebut berada akan mensyaratkan prosedur yang ketat untuk repatriasi aset tersebut.

Keberhasilan program pengampunan pajak ini akan diukur dari pencapaian tujuan-tujuan yang telah ditetapkan. Dari uraian di atas nampak bahwa hampir semua tujuan yang ingin dicapai oleh Pemerintah Indonesia diperkirakan mempunyai peluang besar untuk tercapai, kecuali tujuan repatriasi aset yang diperkirakan lebih kecil peluangnya untuk dapat berhasil. Tujuan yang harapannya besar untuk tercapai adalah: (i) peningkatan penerimaan pajak jangka pendek yang berasal dari uang tebusan; (ii) perluasan basis pengenaan pajak yang secara tidak langsung akan berdampak pada peningkatan penerimaan jangka panjang; (iii) peningkatan kepatuhan wajib pajak sebagai akibat banyaknya pihak yang diperkirakan akan berpartisipasi dalam program pengampunan pajak ini, baik yang sudah menjadi wajib pajak maupun yang belum menjadi wajib pajak; hal ini sekaligus juga akan mengurangi pelaku ekonomi dan bisnis yang tergolong shadow/underground economy; (iv) menjadi jembatan (bridge) yang berguna bagi wajib pajak dalam menyongsong dan menuju era keterbukaan informasi (Automatic Exchange of Information). Capaian (i) dan (ii) merupakan capaian tujuan yang secara tersirat sudah disampaikan oleh Direktorat Jenderal 
Pajak dalam sosialisasi yang dilakukan, sedangkan capaian (iii) dan (iv) merupakan capaian positif yang dapat terealisasi sebagai dampak jika program pengampunan pajak ini sukses dalam implementasinya.

\section{KESIMPULAN}

1. Program pengampunan pajak adalah program kontroversial yang dilaksanakan oleh banyak negara di seluruh dunia untuk meningkatkan penerimaan pajaknya, khususnya pada saat-saat di mana negara tersebut menghadapi tekanan dalam mencapai target penerimaan pajak dalam rangka pembiayaan belanja untuk keperluan publik, misalnya pada saat krisis/resesi ekonomi.

2. Pada umumnya pelaksanaan program pengampunan pajak dimaksudkan untuk meningkatkan penerimaan pajak, baik untuk jangka pendek maupun jangka panjang, memperluas basis pemajakan, meningkatkan kepatuhan wajib pajak, menarik dana milik wajib pajak yang berada di luar negeri untuk migrasi ke dalam negeri dan tujuan-tujuan khusus lainnya yang hendak dicapai oleh pemerintah di masing-masing negara.

3. Walaupun mempunyai banyak manfaat, program pengampunan pajak juga memiliki banyak dampak negatif, sehingga negara yang akan melaksanakan program pengampunan pajak harus berusaha mengeliminasi dampak negatif ini.

4. Dalam pelaksanaannya tidak semua negara sukses mengimplementasikan program pengampunan pajak, artinya tujuan yang hendak dicapai sering tidak terealisasi.
5. Dengan mengeloborasi pengalaman kesuksesan dan kegagalan pelaksanaan program pengampunan pajak yang dilaksanakan banyak negara, maka diprediksi bahwa program pengampunan pajak yang dilaksanakan oleh Pemerintah Indonesia saat ini secara umum mempunyai peluang besar untuk sukses dan memenuhi harapan.

6. Walaupun diperkirakan sebagian besar tujuan pelaksanaan program pengampunan pajak yang dilaksanakan oleh Pemerintah Indonesia akan berhasil, namun untuk tujuan repatriasi dana dari luar negeri ke dalam negeri kelihatannya tidak akan sesukses dengan capaian tujuan-tujuan lainnya.

\section{SARAN}

1. Undang-Undang yang dipersiapkan untuk perubahan Undang-Undang Perpajakan yang ada pasca berakhirnya periode pengampunan pajak, hendaknya memberikan kewenangan yang lebih bagi Direktur Jenderal Pajak untuk melakukan penegakan hukum, khususnya bagi wajib pajak yang telah terbukti melakukan tax evasion berkesinambungan.

2. Undang-Undang yang dipersiapkan untuk perubahan Undang-Undang Perpajakan yang ada pasca berakhirnya periode pengampunan pajak hendaknya juga dapat mengakomodir solusi permasalahan-permasalahan dan kesulitan-kesulitan yang dialami oleh wajib pajak dalam memenuhi kewajiban perpajakannya.

3. Pemerintah Indonesia harus mempertimbangkan untuk menurunkan tarif pajak pasca berakhirnya periode pengampunan pajak, karena 
pengalaman yang ada menunjukkan penurunan tarif pajak pasca berakhirnya periode pengampunan pajak akan mampu mendukung keberhasilan implementasi program pengampunan pajak secara keseluruhan, terutama untuk peningkatan penerimaan pajak yang bersifat jangka panjang dan berkelanjutan.

4. Di samping perubahan-perubahan yang perlu dilakukan terhadap Undang-Undang Perpajakan dan peraturan pelaksana lainnya, deregulasi secara struktural juga perlu dilakukan dalam segala bidang untuk mendukung keberhasilan program pengampunan pajak ini.

\section{DAFTAR KEPUSTAKAAN}

Alm, James, Jorge Martinez-Vasquez and Sally Wallace, 2007, Do Tax Amnesties Work? The Revenue Effects of Tax Amnesties During The Transition in The Russian Federation, International Studies Program, Working Paper 07-18, Andrew Young School of Policy Studies, Georgia State University.

Andreoni, James, 1991, The Desirability of a Permanent Tax Amnesty, Journal of Public Economics 45, page 143-159.

Bayer, Ralph-C, Harald Oberhofer and Hannes Winner, 2015, The Occurence of Tax Amnesties: Theory and Evidence, Journal of Public Economics, 125 , page $70-82$.

Bose, Pinaki and Michael Jetter, 2010, A Tax Amnesty in The Context of a Developing Economy.

Farrar, Jonathan, Cass Hausserman and Paul Dunn, 2014, The Influence of Guilt Cognition on Taxpayers' Amnesty Disclosures.

İpek, Selçuk, Mehmet Öksüz and Sibel Özkaya, 2012, Considerations of Taxpayers According to Situation of Benefiting From Tax Amnesty: An Empirical Research, International Journal of Business and Social Science, Vol. 3, No. 13, page 95101.

Kilonzo, Tom Mutemi, 2012, The Effects of Tax Amnesty on Revenue Growth in Kenya, A Research Project Submmited in Partial Fulfillment of The Requirement for The Award of The Degree of Master in Business Administration, University of Nairobi.

Marchese, Carla, 2014, Tax Amnesties, IEL Paper in Comparative Analysis of Institutions, Economics and Law No. 17.

Mattiello, Giovanni, 2005, Multiple Tax Amnesties and Tax Compliance (Forgiving Seventy Times Seven), Working Paper 06/2005, Universita Ca'Foscari, Venezia.

Mouloud, Melikaoui, 2015, The Tax Amnesty Program: as Tool to Adjust The Shadow Economy; The International Experiences, Global Advanced Research Journal of Economics, Accounting and Finance, Vol. 3, No. 2, page 17-25.

Nar, Mehmet, 2015, The Effects of Behavioural Economics on Tax Amnesty, International Journal of Economics and Financial Issues, Vol. 5, Issue 2, page 580-589.

Peraturan Direktur Jenderal Pajak Nomor PER-07/PJ/2016 tentang 
Dokumen dan Pedoman Teknis Pengisian Dokumen dalam Rangka Pelaksanaan Pengampunan Pajak sebagaimana telah diubah dengan Peraturan Direktur Jenderal Pajak Nomor PER-10/PJ/2016.

Peraturan Direktur Jenderal Pajak Nomor PER-11/PJ/2016 tentang Pengaturan Lebih Lanjut Mengenai Pelaksanaan Undang-Undang Nomor 11 Tahun 2016 tentang Pengampunan Pajak.

Peraturan Direktur Jenderal Pajak Nomor PER-17/PJ/2016 tentang Tata Cara Penyampaian Surat Pernyataan bagi Wajib Pajak Tertentu serta Tata Cara Penyampaian Surat Pernyataan dan Penerbitan Surat Keterangan bagi Wajib Pajak dengan Peredaran Usaha Tertentu.

Peraturan Direktur Jenderal Pajak Nomor PER-20/PJ/2016 tentang Tata Cara Penerbitan dan Pengiriman Surat Keterangan Pengampunan Pajak.

Peraturan Menteri Keuangan Republik Indonesia Nomor 118/PMK.03/ 2016 tentang Pelaksanaan UndangUndang Nomor 11 Tahun 2016 tentang Pengampunan Pajak sebagaimana telah diubah dengan Peraturan Menteri Keuangan Republik Indonesia Nomor 141/PMK.03/2016.

Peraturan Menteri Keuangan Republik Indonesia Nomor 119/PMK.08/ 2016 tentang Tata Cara Pengalihan Harta Wajib Pajak ke dalam Wilayah Negara Kesatuan Republik Indonesia dan Penempatan pada Instrumen Investasi di Pasar
Keuangan dalam Rangka Pengampunan Pajak sebagaimana telah diubah dengan Peraturan Menteri Keuangan Republik Indone-sia Nomor 123/PMK.08/2016.

Peraturan Menteri Keuangan Republik Indonesia Nomor 122/PMK.08/ 2016 tentang Tata Cara Pengalihan Harta Wajib Pajak ke dalam Wilayah Negara Kesatuan Republik Indonesia dan Penempatan pada Investasi di luar Pasar Keuangan dalam Rangka Pengampunan Pajak.

Peraturan Menteri Keuangan Republik Indonesia Nomor 127/PMK.010/ 2016 tentang Pengampunan Pajak Berdasarkan Undang-Undang Nomor 11 Tahun 2016 tentang Pengampunan Pajak bagi Wajib Pajak yang Memiliki Harta Tidak Langsung Melalui Special Purpose Vehicle sebagaimana telah diubah dengan Peraturan Menteri Keuangan Republik Indonesia Nomor 142/PMK.010/ 2016.

Ross, Justin M. and Neal D. Buckwalter, 2013, Strategic Tax Planning for State Tax Amnesties: Evidence From Eligibility Period Restrictions, Public Finance Review, 41, page 275-301.

Uchitelle, Elliot, 1989, The Effectiveness of Tax Amnesty Programs in Selected Countries, FRBNY Quarterly Review Autumn.

Undang-Undang Republik Indonesia Nomor 11 Tahun 2016 tentang Pengampunan Pajak. 